\title{
8
}

\section{CARETAKER GOVERNMENTS IN BELGIUM}

\author{
The new normal?
}

\author{
Régis Dandoy and Lorenzo Terrière
}

\subsection{Introduction}

Yves Leterme took oath as prime minister of Belgium on 20 March 2008, concluding a political crisis that started almost one year earlier. But the Christian democratic leader is not remembered for being the prime minister who managed to handle the financial crisis or who failed to reach an agreement on the sixth Belgian state reform. He will rather be remembered for an odd record: out of his 1026 days as Belgian prime minister, Leterme spent more than half of it (59.55\%) as chief of a caretaker government (cabinets Leterme I and II). This remarkable statistic illustrates that caretaker governments are not an extraordinary phenomenon in Belgian politics. Instead, they are becoming an integral part of the political dynamics in this country.

Caretaker periods mark the transition between the termination of one government and the start of another. If the end of a cabinet and the kickoff of a new one are considered goldmines for political scientists working on elections, executives and ministerial careers, these intermediary periods did not receive the same research attention, however. Literature on caretaker governments is particularly scarce (Boston et al., 1998; Courtenay Ryals \& Golder, 2010; Schleiter $\&$ Belu, 2015) and comparative works are lacking. Yet, many West European countries have witnessed more or less long periods of caretaker governments, mostly in-between elections or in relation to government formation. Think, for instance, about the political and institutional relevance of caretaker governments in Greece, Ireland, the Netherlands and Spain in recent years.

But compared to Belgium, these countries compete in the featherweight or lightweight categories. Belgium is without any doubt the most famous player of the heavyweight category of caretaker cabinets. Between 2007 and 2020, Belgium was governed for no less than 1485 days by a caretaker government, 
which equals to more than four full calendar years. In comparison, Poland experienced 414 days without a duly mandated government in office between 1991 and 2008 (Courtenay Ryals \& Golder, 2010). The longest episode of caretaker government is spread over 597 days (in 2010-2011) in Belgium while the record in the Netherlands is 'only' of 208 days without a full-powered government in 1977 (Diermeier \& Van Roozendaal, 1998). During this period, Belgium coped with the financial crisis and even nationalized banks, went to war with Libya, sent humanitarian support to other countries and successfully presided over the European council for half a year.

Given its importance in contemporary politics, it is not surprising that political science in Belgium is interested in the study of this recurring phenomenon. The root causes leading to lengthy caretaker governments are well known and covered in the relevant literature. In fact, we are now fully capable of explaining why Belgian fights alone in its own category. Yet, we know surprisingly little about the actual consequences of these caretaker governments when we look at the international scholarly literature. Most comparative datasets simply ignore caretaker governments and prefer to focus on the political and policy impacts of the 'normal' governments. Therefore, in this chapter, we open the black box of caretaker governments by investigating their political and policy consequences in the Belgian context.

This chapter is structured as follows. Section 8.2 sets out the definition and main characteristics of caretaker governments and gives a brief quantitative account of the importance of this political phenomenon in the last two decades in Belgium. Section 8.3 investigates the consequences a caretaker government generates for the stability and popularity of the sitting cabinet. Section 8.4 analyzes the types of actions that caretaker governments can undertake and tests whether the scope of actions tends to increase over time. Finally, and based on the detailed analysis of the Belgian caretaker cabinets between 2007 and 2020, Section 8.5 discusses the main empirical findings that we have brought forward in this chapter.

\subsection{Definition and measurement of caretaker governments in Belgium}

After its resignation or its removal by parliament, an executive is supposed to cease its activities immediately. The rationale behind this is that the dismissed cabinet cannot take any further decisions or actions that would compromise the future responsibilities of the next cabinet. In parliamentary regimes (and in consociational democracies in particular), a new full-fledged cabinet only takes power after its investiture vote in parliament; after new elections; after a transitory government ${ }^{1}$; and/or after an agreement between the main political actors (Boston et al., 1998). These events often take weeks, if not months. In the meantime, the sitting government remains in power until it has been replaced and is henceforth labeled as 'caretaker'. Using the words of Hooghe (2012b), "no matter how long that might take, the earlier government simply has to soldier on". 
The comparative international literature investigated caretaker governments and identified a shared set of key characteristics. A first characteristic of a caretaker government is that it ensures continuity. Indeed, it is necessary to avoid a complete absence of the executive power since this could be detrimental to the country and the population. Therefore, the resigning or removed cabinet cannot immediately leave office but instead needs to remain in power until its successor is appointed (Schleiter \& Belu, 2015). In that way, caretaker governments fulfill a 'bridging role' between the duly mandated governments (McDonnell \& Valbruzzi, 2014).

The second characteristic of a caretaker government concerns its limited scope and range of political actions. Such a government is only 'taking care' of those cabinet functions and duties for which continuity seems essential. The government refrains from taking any further decisions that may burden the incoming government, whereby it restricts itself to preserving the 'policy status quo' (Boston et al., 1998; Davis et al., 2001; Schleiter \& Belu, 2015). Thus, a caretaker government does not undertake new political initiatives and postpones all significant decisions until the new government takes over.

A third and last characteristic deals with the fact that caretaker governments do not enjoy large political legitimacy. The sitting cabinet may have lost a vote of confidence in parliament without new legislative elections and/or a new vote of confidence in parliament took place. This conflicts with the principle of the political accountability of the executive branch vis-à-vis the legislative branch. Since the former government has resigned or is removed, its actions can no longer be controlled by the parliament. The legislative power cannot cast another vote on a motion of no confidence against an - already - removed executive. ${ }^{2}$

Given their high presence throughout the last two decades, caretaker governments have become relevant political phenomena in Belgium. This uprising has not gone unnoticed by political scientists: important pieces of literature on federal politics in Belgium investigate caretaker governments. Scholarly works explored the problems of public governance at the federal level and discussed reasons why caretaker governments emerge. Several structural explanations have been put forward such as the consociational system of decision-making, the electoral system, the fragmented party system, the absence of national parties and the linguistic and territorial conflicts, as well as conjunctural explanations such as the success of a nonmainstream party, the disagreement on territorial reforms, the ideological distance between the mainstream parties or even the chicken game during the negotiation talks (Albalate \& Bel, 2020; Brans et al., 2016; Deschouwer, 2012; Golder, 2010; Hooghe, 2012a; Van Aelst \& Louwerse, 2014). Works in the Belgian academia also question the robustness and the resilience of the political system and scholars have tried to explain how a complex country such as Belgium can continue to function even when a caretaker government is in the driving seat (Albalate \& Bel, 2020; Bouckaert \& Brans, 2012; Brans, 2012; Brans et al., 2016; Deschouwer, 2012; Devos \& Sinardet, 2012; Hooghe, 2012a,b; Pilet, 2012). 
As for the specific Belgian context, there is no tailor-made definition for what resembles a caretaker government. Like in many other parliamentary regimes (Boston et al., 1998), the political phenomenon of a caretaker government is absent from the legal constitutional framework. Caretaker governments are only briefly mentioned in the special Law on Institutional Reforms of 8 August 1980, where it is stipulated that "as long as it has not been replaced, the demissionary cabinet remains caretaker". Instead, the definition of a caretaker cabinet is determined by customary law and practice (Bernard, 2020; Rigaux, 2020), which has been confirmed by the Council of State in 2016 (decision 234.747 on 17 May 2016). In that respect, a common standard acceptance is that caretaker governments in Belgium limit themselves to just certain types of actions, like daily matters, ongoing matters (i.e. policy continuity) and urgent matters. However, there is little consensus among scholars about that the exact list of these actions (see Section 8.3).

For sure, there have been various types of cabinets in Belgium over the last decades: coalition cabinets, minority cabinets, transitory cabinets, etc. To distinguish caretaker governments from these other types, we define a caretaker period as the time interval during which either one of the two political branches (executive or legislative) does not enjoy its full powers (Bernard, 2020; Dandoy \& Terrière, 2021; Rigaux, 2020).

Following this straightforward definition of a caretaker government, we can measure the exact length of caretaker periods for the last decades in Belgian political history. The three longest caretaker governments are all in recent years: 235 days in 2007, 457 days in 2018-2020 and 597 days in 2010-2011. When adding the other (shorter) caretaker governments in recent history, we account that Belgium was ruled by a caretaker government for no less than 1485 days between 2007 and 2020. This corresponds to $29.04 \%$ of the total period between the 1 st January 2007 and the 31 August 2020, or more than four (!) full calendar years. ${ }^{3}$

\subsection{The political consequences of a caretaker regimen}

A caretaker cabinet does not only affect the capacity of the executive but also of other political institutions. We highlighted in the first section that issues related to democratic legitimacy are crucial in the context of caretaker governments who cannot be held accountable by their parliaments. In that respect, the nature of the relationship between the legislative and the executive branch has been at the center of attention of the specific scholarly literature on caretaker governments (e.g. Devos \& Sinardet, 2012). Since the cabinet is already dismissed, a caretaker government cannot be sanctioned once again by parliament. This eliminates a major instrument of political power held by the members of parliament in a normal democratic system.

In a parliamentary democracy such as Belgium, the executive is controlled by the legislative branch but it surely dominates the overall lawmaking process. Prior works on caretaker cabinets in Belgium investigated this institutional 
relationship and tested whether parliament has larger influence on the legislative process in caretaker periods (cf. Brans et al., 2016; Pilet, 2012; Van Aelst \& Louwerse, 2014). Empirical analyses of the 2007-2011 period show a nuanced picture. If the parliament took more legal initiatives than in normal times, caretaker periods did not lead to drastic changes in the legislative-executive relationship but rather permitted a modest correction to the extremely weak position of the Belgian parliament (Van Aelst \& Louwerse, 2014).

In Belgium, MPs are constrained by partisanship and party discipline. Scholars have investigated whether MPs enjoy more freedom in caretaker periods since one would expect that there is less party discipline. Empirical analyses of the 2010-2011 caretaker period have demonstrated that, despite the caretaker regime, parties have remained extremely cohesive, party discipline has remained strong and vote dissention was still exceptional (Brans et al., 2016; Pilet, 2012). Moreover, Van Aelst and Louwerse (2014) observed that, in times of institutional crisis, parties are even more coherent in terms of voting than in regular periods. The government-opposition divide still leads to clustered legislative party positions, and this even if alternative majorities sometimes emerge - especially between parties negotiating for the formation of a next federal cabinet (Baeselen et al., 2014; Pilet, 2012; Van Aelst \& Louwerse, 2014).

While caretaker periods might affect the functioning of federal entities (e.g. parliament or administration ${ }^{4}$ and their relationship vis-à-vis the executive), the relevant literature on caretaker cabinets in Belgium overlooks its impact on the sitting government itself. Therefore, in this section, we investigate the political consequences for those parties that take part in the caretaker cabinet. First, we investigate whether cabinets are more stable during caretaker periods. Since one of the main characteristics of a caretaker government is that it ensures continuity and that the country should never be without a functioning executive, the same reasoning applies to individual ministers. Similarly to what we expect from the cabinet as a whole, ministers should remain in power until their successor is appointed.

We test this hypothesis of ministerial stability by a detailed analysis of the eight episodes of a caretaker cabinet between the 12 July 2003 and 31 August 2020 and compare these with periods of 'normal' cabinets. Ministerial instability is an important phenomenon in Belgian politics: there are three resignations per year on average in recent decades (Dumont et al., 2008). From 2003 till 2020, this figure is slightly lower with just over two resignations per year on average. We observe in Table 8.1 that there are generally more ministerial resignations during caretaker periods than in normal periods. Specifically, a caretaker cabinet that lasts for one year witnesses no less than 2.46 resignations, which is significantly more than in a cabinet with full powers (i.e. 1.9 resignations per year). Hence, our hypothesis of higher ministerial stability in case of caretaker government is rejected.

A detailed analysis of the rationales behind these resignations reveals an interesting pattern. None of the ten ministerial resignations during caretaker periods 
TABLE 8.1 Ministerial stability in the federal cabinet

\begin{tabular}{llrrr}
\hline \multicolumn{1}{c}{ Years } & Type of cabinet & Period $(\mathrm{N}$ days) & $\begin{array}{c}\text { Ministerial } \\
\text { resignations }\end{array}$ & $\begin{array}{c}\text { Resignations } \\
\text { (per year) }\end{array}$ \\
\hline $2003-2007$ & Full powers & 1390 & 11 & \\
2007 & Caretaker & 235 & 2 & \\
$2007-2008$ & Full powers & 88 & 0 & \\
2008 & Caretaker & 3 & 0 & \\
2008 & Full powers & 114 & 1 & \\
2008 & Caretaker & 3 & 0 & \\
2008 & Full powers & 155 & 0 & \\
$2008-2009$ & Caretaker & 14 & 0 & \\
2009 & Full powers & 327 & 4 & \\
2009 & Caretaker & 3 & 0 & \\
$2009-2010$ & Full powers & 146 & 0 & \\
$2010-2011$ & Caretaker & 597 & 1 & \\
$2011-2014$ & Full powers & 866 & 3 & \\
2014 & Caretaker & 175 & 4 & \\
$2014-2018$ & Full powers & 1524 & 6 & \\
$2018-2020$ & Caretaker & 457 & 3 & \\
2020 & Full powers & 165 & 0 & \\
Total & Full powers & 4775 & 25 & \\
Total & Caretaker & 1485 & 10 & \\
\hline
\end{tabular}

*Prime ministers excluded.

are due to political motives or scandals. Rather, all of these ten ministers or state secretaries resigned to occupy an alternative position in another institution, as, for instance, Didier Reynders who entered the European commission in 2019. In other words, it seems that caretaker ministers chose to boost their future political career when opportunities arise rather than to ensure the continuity of the federal cabinet. Similar observations are made when it comes to cabinet staff members, of whom a high proportion left the cabinet services well before the end of the caretaker period (Brans, 2012).

Until 2019, no Belgian prime minister ever resigned during a caretaker period. For instance, in 2011, Prime Minister Yves Leterme kept his future leadership position within the OECD on hold until the Di Rupo cabinet finally took office. Yet, in October 2019, Prime Minister Charles Michel left the federal cabinet to prepare for a new international role as president of the European Council. Sophie Wilmès was appointed on the same day as Michel's resignation. She confirmed that the rest of the cabinet's composition would remain unchanged, and it kept in a caretaker mode until a new full-fledged coalition government would take office.

Next to the analysis of ministerial stability in caretaker governments, this section also investigates the effect of caretaker periods on election results and on party popularity. As one can imagine, these delicate moments in political history did not remain unnoticed by the population. For example, during the 2010-2011 caretaker episodes, there were frequent marches on the streets of 
Brussels, combined with public initiatives to start direct dialogues between the linguistic communities (Bouckaert \& Brans, 2012). The question is then whether parties who participate in such caretaker governments are punished or rewarded by the population and the electorate.

First, we assess the electoral performance of parties in caretaker governments. We know from prior works that Belgian governing parties tend to lose the elections that follow their cabinet participation (Dandoy, 2018; Dumont \& De Winter, 1999). With the exception of the Verhofstadt I cabinet in 2003, governing parties have always lost an important share of votes in the consecutive elections since 1999. Governments in a long caretaker period before the elections are no exception to these findings. For instance, while the coalition parties of Michel II were in caretaker mode for already more than five months, they suffered a combined loss of $6.04 \%$ vote shares in the 2019 elections. This is not significantly different from the electoral losses of governing parties in shorter caretaker periods. Thus, the fact that a cabinet resigns (long) before the end of the legislative term does not impact its electoral performance.

Second, we measure the popularity of parties in the caretaker government. In a caretaker cabinet, the classic divide between government and opposition does not apply. Voters may want to reward parties for holding up the country during a political crisis or, on the contrary, may want to punish these same parties for not finding a proper solution to this crisis. Analyzing opinion polls for the period 2008-2013, we observe that a caretaker period does not generate an important impact on the popularity of governing parties. In general, political parties in government become more unpopular over time, and this independent from the nature of the cabinet, i.e. a caretaker one or one operating in its full capacity.

\subsection{Caretaker governments and actual policymaking}

The absence of a democratic mandate to operate in its full capacity limits the political maneuvering space of any caretaker government. Deprived of the required electoral legitimacy and parliamentary support, these cabinets will need to thread with caution. Yet, public governance and decision-making need to continue, even under these inconvenient circumstances, to safeguard the vital interests of the country and its inhabitants. This third section investigates the broad academic consensus that lives under both legal experts and political scientists about which specific policy initiatives a caretaker government can (not) undertake. In what follows, we bring together the current scholarly literature by drafting an own typology of six different actions that fall under the scope of caretaker governments.

In addition, we hypothesize that there is a strong tendency to stretch the political range of action - for each of these six types of actions - the longer the caretaker cabinet remains in executive office. Previous scholars (Boston et al., 1998; Bouckaert \& Brans, 2012; Pastorella, 2016) have suggested that such a dynamic may exist for some specific governmental acts. Yet, if such a renewed political 
assertiveness appears as an overall and reoccurring phenomenon, one may argue that it is actually deliberate strategy of a caretaker government to regain its former political maneuvering space.

Most prior works (e.g. Bouckaert \& Brans, 2012; Devos \& Sinardet, 2012; Van Aelst \& Louwerse, 2014) investigating the impact of caretaker governments on actual policymaking in Belgium have focused on the long-lasting political crisis of 2010-2011. Instead, we opt to turn the spotlight on the more recent political stalemate of 2018-2020, which started with the downfall of the full-fledged coalition government Michel I. Interestingly, legislative elections were organized halfway through this long-lasting crisis (May 2019), after which the caretaker period simply continued to drag on. Since the occurrence of elections in the middle of a caretaker period is highly unusual, we test whether this event had an impact on the kind and the nature of the decisions taken by the caretaker cabinet before and after the elections - and thus also: before and after the installation of a new parliament. Inserting this reference point enables us to get more insight in a caretaker cabinet's (increasing) range of actions over time, and whether such specific events generate an impact here. Also, we compare our findings with those from the 2010-2011 crisis (597 days) to better understand the 2018-2020 stalemate (457 days).

This section relies on the analysis of the minutes of the weekly cabinet decisions taken between 9 December 2018 (i.e. the downfall of the Michel I cabinet) and 19 March 2020 (i.e. when the Wilmès II cabinet obtained the vote of confidence in Parliament). In Belgium, joint cabinet meetings are organized once a week, usually on Friday mornings. It is during these recurring key moments that most political decisions are taken for the various federal departments: ministers present and defend their policy proposals to their colleagues and this is followed by a discussion and bargaining procedure. Afterward, a brief report of the outcome is published on the website of the Belgian government. These weekly summaries of the main policy decisions are a transparent and reliable instrument to measure the evolving policy scope of the sitting government.

Mapping these documents provides us with empirical evidence to test both hypotheses: can we speak of (a) an increasing range of actions and if so, is it (b) a reoccurring phenomenon throughout the six different types of political actions? We expect that in an early stage, the resigning executive is cautious not to spread its operational wings too much. This initial self-restraint is likely to be eased as time progresses, however. In this respect, earlier authors (e.g. Hooghe, 2012a) refer to situations where negotiations kept dragging on, leading to unprecedented lengths of a caretaker period.

In a belated stage, the caretaker cabinet may take up a more proactive stance and even initiate new political initiatives (Schleiter \& Belu, 2015). We concur with this reasoning and hypothesize that, once new elections took place and a new parliament is installed, a more expansive approach from the caretaker government vis-à-vis actual policymaking becomes visible. In addition, we may also expect a larger scope of actions when there is a change in the position of prime minister. 
Namely, a new PM means new dynamics and he/she may not feel bound to the cautious behavior of her/his predecessor. Applied to this study, it means that after 26 October 2019, we may expect the caretaker government to display a significant (quantitative and qualitative) increase in its range of political actions, since from that moment onward, Sophie Wilmès took over from Charles Michel, who became President of the European Council. Last but not least, we might see a larger scope of action at the end of the calendar year since many legal initiatives and government programs are supposed to end on the 31 December - e.g. the annual budget laws. We investigate whether these expectations are true for key federal policy domains such as budget, defense, asylum and migration and social security.

Underneath, we aim to summarize the academic consensus among legal experts and political scientists about which specific policy initiatives a caretaker government can (not) undertake. We distinguish no less than six different types of policy actions. Classic studies about caretaker cabinets in Belgium focus on the first three types (e.g. Brans et al., 2016; Devos \& Sinardet, 2012; Hooghe, 2012 b) but more recent ones also add several others to these first categories (e.g. Schleiter \& Belu, 2015; Van Aelst \& Louwerse, 2014). The latter also focus on international obligations (4), new initiatives from parliament (5) and even new initiatives from the government itself (6). Especially the prominence of this last category makes Belgium an exceptional and deviant case from other countries (Davis et al., 2001; Hloušek \& Kopeček, 2014; Tiernan \& Menzies, 2007).

A first type of action of a Belgian government during a caretaker period concerns the 'daily management' of the state (e.g. Baeselen et al., 2014). These decisions generally do not concern political sensitive topics - take, for instance, the salary payments of civil servants or paying the energy bills of public buildings. Important nominations within the human resources management department fall outside of this scope. Initially, when looking at the political stalemate of 2018-2020, new appointments in the administration, military and judiciary are put on hold. However, once the new PM Wilmès took office, the cabinet started to resolve high-level personnel matters, among which several appointments of key management positions within the public administration. For example, it renewed the executive mandates for the sitting administrator-general of the Social Security e-services (approved on 24 January 2020) and Real Estate administrator of the Federal Government (approved on 31 January 2020) for another six (!) years.

A second type of actions constitutes issues that were approved and initiated in the past when the government still enjoyed its full powers (e.g. Baeselen et al., 2014). Similar to the first type, the necessity of this category is based on the argument that the public governance of the country requires continuity. Taken together, these first two types of actions are often described by the notion of 'current affairs' (e.g. Devos \& Sinardet, 2012). Throughout the 2018-2020 caretaker period, the federal administration continued to function thanks to the guaranteed but temporary budget laws that were adopted - the so-called provisionary twelfths. These budget proposals were still initiated by the caretaker cabinet and 
had to be formally approved by the Parliament every three months. At first, the budgetary framework was accepted without any further amendments. Yet, the version that was laid down in March 2020 was only approved after no less than 27 plenary amendments from various political parties were put to the vote as well. In this last budget bill under the regime of a caretaker government, the initial path of 'provisionary twelfths' was diverted at several programs, among which the health-care budget was increased with several hundred million euros. After the new PM Wilmès took office, the initial restraint and continuity is swapped for a more extensive range of political actions. Take, for example, the cabinet decision to start building a new prison in the municipality of Dendermonde. This longawaited ruling by the Minister of Justice was finally taken on 14 February 2020. It is somewhat paradoxical that this highly delicate political decision - due to many years of continued international pressure to improve the facilities for prisoners as well as domestic arm-wrestling about where this extra capacity would be allocated - was taken by a caretaker government in its final days.

A third type of actions entails 'urgent matters' (e.g. Hooghe, 2012a). A caretaker government may need to take measures because any delay or nonaction could cause damage to the state or its inhabitants. Just like in other categories, this concept is a 'moving target': its interpretation is susceptible to evolutions in the context and circumstances (Baeselen et al., 2014). During the 2018-2020 period, the caretaker government was confronted with the upcoming deadline of the 'Brexit'. Yet, it was only on 17 January 2020 (i.e. again after the appointment of a new PM) that a series of important fiscal transition measures were taken by the caretaker government to prevent important economic and financial losses. Furthermore, the unexpected outbreak of the Covid-19 forced the caretaker cabinet Wilmès I to introduce drastic sanitary and safety measures to contain the spreading of the virus. They did this even before 19 March 2020 - i.e. the day when the cabinet actually proceeded again under its full powers.

Fulfilling the international commitments and obligations (incl. EU and NATO) is a fourth type of actions that a caretaker government needs to cover. This includes, for example, also the speedily transposition of EU directives in Belgian legislation. When discussing the 2010-2011 period, scholars often refer to the decisions of the Leterme II cabinet to go to war with Libya (Bouckaert \& Brans, 2012; Schleiter \& Belu, 2015) and to participate in the EU programs to save the euro (Devos \& Sinardet, 2012; Hooghe, 2012a). Likewise, during the 2018-2020 period, the Belgian caretaker government lived up to its international obligations. But it was only after Wilmès took over as PM that important new initiatives were undertaken such as the nomination of Didier Reynders as European Commissioner. On 7 February 2020, a series of measures were decided to prevent money laundering and the financing of international terrorism - as this was requested by several international organizations. Also, on 14 February 2020, Belgium decided to send out a mission to Albania to provide immediate help and assistance after an earthquake had hit the region and to Bolivia where forest fires destroyed many people's houses (20 December 2019). 
A fifth task that caretaker cabinets have to deal with is legal initiatives decided by parliament. Indeed, a resigning cabinet may open up opportunities for parliament to step in and to take up a larger role in policymaking, hereby creating ad-hoc coalitions for all kinds of legislative proposals. This happened in 2018-2020 as parliamentary initiatives were passed that even amended existing royal decrees and ministerial decrees. Bear in mind that, when adopting such detailed legislation, parliament actually treads on governments' territory. Three vivid examples were the decisions (a) to improve the social tariffs on gas and electricity; (b) to grant a financial compensation to employees who go to work by making use of the e-bike and (c) and to increase the pensions for underground mine workers.

A sixth and last type are new initiatives that the caretaker government initiates by itself (Schleiter \& Belu, 2015). This is actually a controversial category that many scholars do not even consider falling within the scope of a caretaker cabinet. Yet, it is surely present in Belgian political practice. The apparent switch in the function of PM also generates actions for this last type if we take a closer look the 2018-2020 caretaker period. Only in a belated stage, the caretaker cabinet began to initiate own and far-reaching policies that are a clear departure from the status quo. For example, the cabinet decided to change what kind of personal information needs to be mentioned on a citizens' identity card (14 February 2020); obliged the registration of a person's fingerprints on every identity card (12 December 2019) and approved a 'national emergency plan' in case of a terrorist attack including the erection of new surveillance structures and response procedures (24 January 2020).

Now that we have identified six types of actions, we add two important observations. These underline the strong tendency to increase the range of political actions over time. First, it is only in the few weeks before and after an election, during which parliament is not in its full powers that we see a significant increase in the number of royal and ministerial decrees undertaken by the caretaker cabinet. Surely, since it is temporarily more difficult to realize new legislation through the legislative branch because the cabinet is not supported by a parliamentary majority, the caretaker government may try to fulfill its agenda through alternative means within the executive branch.

Second, if parliament enjoys more leeway during a caretaker period, ministers may feed parliamentarians even more with ready-made bills. By making use of this institutional shortcut, individual ministers (even in a caretaker mode) try to speed up the decision-making process and complete some of their initial projects. For parliamentarians, it means an opportunity to score publicly without the effort of having to write a complex legal piece. A good example from the 2018-2020 period is the legal proposal in Parliament to lower the costs of anti-conception for younger women approved on 16 July 2020 after this measure was agreed in principle during a prior meeting of the caretaker cabinet (21 February 2020).

This section has identified and discussed different types of actions that fall under the scope of a 'caretaker cabinet'. Most of them enjoy broad academic consensus among political scientist and lawyers. Through an assessment of the 20182020 caretaker period in Belgium, we have demonstrated that long transition 
periods trigger caretaker executives to expand their range of political actions over time. We provided empirical evidence for this expansive behavior for every different type of action. It actually seems a broad and general trend, which renders omnipresent in every type of action. Given this constituent and reoccurring pattern, one may argue that this is a deliberate strategy. More than a year after the downfall of the government, the remaining members of the executive branch will still have a longing desire to realize their initial agenda and the projects they had mind. This continued policy ambition could be an important explanation for this increasing range of political actions over time that we have observed.

\subsection{Conclusion}

Belgium is famous for the length of its government formation processes. During these periods, the former federal coalition government keeps acting as a caretaker cabinet but it operates with limited political and policy powers. Yet, political deadlocks are merely the tip of the iceberg, as federal elections and other major political crises have led to shorter or longer situations of a federal caretaker government. With a focus on the last two decades, this chapter observes that Belgium was ruled by a caretaker government for no less than 1485 days between 2007 and 2020, corresponding to more than four full calendar years. In many ways, this situation is unique in contemporary politics around the world.

Rather than investigating the origins of caretaker governments and the factors behind such lengthy episodes, this chapter aimed at exploring the political and policy consequences of caretaker governments in Belgium. A first set of findings indicates that caretaker periods do alter the balance of power between federal institutions and political actors: the parliament is not significantly empowered and partitocracy still dominates federal politics. At the same time, our analyses show that the cabinet becomes slightly more unstable (in particular when looking at ministerial turnover) and that parties in government are not particularly rewarded or sanctioned by the voters and the public opinion. Even if these periods saw the emergence of demands for more deliberative and/or direct democracy, the way representative democracy is functioning in Belgium seems to remain largely unchanged, and we observe that the main traditional political actors and institutional dynamics are not affected by caretaker governments.

From the scholarly literature, we derive no less than six different types of actions that fall under the scope of a caretaker government. Belgium is a deviant case from other countries since its caretaker governments even set up new initiatives on its own (type six). Through an exploration of the 2018-2020 caretaker period in Belgium, we have demonstrated that long transition periods trigger cabinets to expand their range of political actions over time. We provided empirical evidence for a constituent and reoccurring pattern for this expansion for every different type of action, indicating a deliberate strategy.

The way ahead is undoubtedly comparative. The analysis of political and policy consequences of caretaker governments apart from the exceptional Belgian case 
may be challenging but will ultimately improve our comprehensive understanding of this complex phenomenon. Are long periods of a caretaker government similarly not affecting the political and party systems in other West European countries, such as Italy, the Netherlands or Spain? It would also be interesting to include technocratic and partisan caretaker governments in the comparative analysis, such as the ones we observe in Finland, Portugal, Sweden or in Central European countries. We particularly call for closer collaboration between researchers studying parties and governments and those analyzing public policies.

Another future field of comparative analysis is related to the impact of the global context and external pressures on the performance of caretaker governments. We know from the Italian case that international actors such as the EU or the IMF have contributed to the thankless implementation of socially difficult reforms. The underlying idea is that, in an extraordinary situation, decision-makers may appreciate a temporary 'relief' of responsibilities for unpopular decisions to a caretaker government (Hloušek \& Kopeček 2014). Even if the financial and economic crisis proved to have only little effect on the Belgian caretaker government in 2010-2011, it would for instance be interesting to observe the impact of the Covid-19 crisis on the politics and policies of the respective caretaker governments. In Belgium, the exceptional sanitary situation led to a sudden end of the Wilmès I caretaker cabinet and triggered the establishment of a temporary minority cabinet.

\section{Notes}

1 Caretaker governments have to be distinguished from interim or transitory governments. This latter kind of cabinets is specifically appointed to make the transition between two governments that benefit from full powers. Alternatively, their sole purpose is to bring the country to (early) elections. Examples of such transitory cabinets can be found in countries such as Italy, Finland, Portugal or Sweden (Beckman, 2007; Courtenay Ryals \& Golder, 2010; Hloušek \& Kopeček, 2014; Larsson, 1994; Magone, 2000; McDonnell \& Valbruzzi, 2014; Zafarullah \& Yeahia Akhter, 2000).

2 Even if parliament cannot sanction the caretaker government as such, it can still control it in principle. For instance, it is not rare to see their ministers being questioned publicly during plenary or committee meetings. Parliamentary consent is also still needed to pass any new legislation.

3 For more information about how to measure caretaker periods and the types of caretaker governments, see Dandoy and Terrière (2021).

4 Devos and Sinardet (2012) observed no increase in the power of the bureaucracy even in times of crises and limited powers. Although the public administration was indispensable in the daily management of current affairs and during the EU presidency in 2011, the authors conclude that bureaucrats did not take over from politicians.

\section{References}

Albalate, D. \& Bel, G. (2020). Do Government Formation Deadlocks Really Damage Economic Growth? Evidence from History's Longest Period of Government Formation Impasse. Governance 33: 155-171.

Baeselen, X., Toussaint, S., Pilet, J.-B. \& Brack, N. (2014). Quelle activité parlementaire en période d'affaires courantes? Cahiers de l'ULB et du PFWB 1. 
Beckman, L. (2007).The Professionalisation of Politics Reconsidered.A Study of the Swedish Cabinet 1917-2004. Parliamentary Affairs 60(1): 66-83.

Bernard, N. (2020). Quelle évolution pour le concept d'affaires courantes? Les focus du CEG 15(1): 4-26.

Boston, J., Levine, S., McLeay, E., Roberts, N. S. and Schmidt, H. (1998). Caretaker Government and the Evolution of Caretaker Conventions in New Zealand. Victoria University of Wellington Law Review 28: 629-648.

Bouckaert, G. \& Brans, M. (2012). Governing without Government: Lessons from Belgium's Caretaker Government. Governance: An International Journal of Policy, Administration, and Institutions 25(2): 173-176.

Brans, M. (2012). Continuity and Change in Belgium's Caretaker Administration. European Political Science 11(1) 102-107.

Brans, M., Pattyn, V. \& Bouckaert, G. (2016). Taking Care of Policy in Times of Crisis: Comparative Lessons from Belgium's Longest Caretaker Government. Journal of Comparative Policy Analysis 18(5): 1-16.

Courtenay Ryals, C. \& Golder, S. N. (2010). Measuring Government Duration and Stability in Central Eastern European democracies. European Journal of Political Research 49(1): 119-150.

Dandoy, R. (2018). Résultats des élections et formation des exécutifs. In F. Bouhon \& M. Reuchamps (Eds.), Les systèmes électoraux de la Belgique. Bruxelles: Bruylant, pp. 517-537.

Dandoy, R. \& Terrière, L. (2021). Caretaker Cabinets in Belgium: A New Measurement and Typology. Politics of the Low Countries 3(1): 95-108.

Davis, G., Ling, A., Scales, B. \& Wilkins, R. (2001). Rethinking Caretaker Conventions for Australian Governments. Australian Journal of Public Administration 60(3): 11-26.

Deschouwer, K. (2012). All Levels Alive. European Political Science 11(1): 108-113.

Devos, C. \& Sinardet, D. (2012). Governing without a Government:The Belgian Experiment. Governance: An International Journal of Policy, Administration, and Institutions 25(2): 167-171.

Diermeier, D. \& Van Roozendaal, P. (1998). The Duration of Cabinet Formation Processes in Western Multi-Party Democracies. British Journal of Political Science 28(4): 609-626.

Dumont P. \& De Winter L. (1999). La formation et le maintien des gouvernements (19461999). Courrier Hebdomadaire du CRISP 1664(39): 1-59.

Dumont P., Fiers S., Dandoy R. (2008). Belgium: Ups and Downs of Ministerial Careers in a Partitocratic Federal State. In K. Dowding \& P. Dumont (Eds.), The Selection of Ministers in Europe. Hiring and Firing. New York, NY: Routledge, pp. 125-146.

Frognier, A-P. (1997). Belgium: A Complex Cabinet in a Fragmented Polity. In J. Blondel \& F. Müller-Rommel (Eds.), Cabinets in Western Europe. London: Palgrave Macmillan.

Golder, S. N. (2010). Bargaining Delays in the Government Formation Process Comparative Political Studies 43(1): 3-32.

Hloušek, V. \& Kopeček, L. (2014). Caretaker Governments in Czech Politics: What to Do about a Government Crisis. Europe-Asia Studies 66(8): 1323-1349.

Hooghe, M. (2012a). The Political crisis in Belgium (2007-2011): A Federal System without Federal Loyalty. Representation 48(1): 131-138.

Hooghe, M. (2012b). Does Multi-Level Governance Reduce the Need for National Government? European Political Science 11(1) 90-95.

Larsson, T. (1994). Cabinet Ministers and Parliamentary Government in Sweden. In M. Laver \& K. A. Shepsle (Eds.), Cabinet Ministers and Parliamentary Government. New York, NY: Cambridge University, pp. 69-182.

Magone, J. M. (2000). Portugal. The Rationale of Democratic Regime Building. In W. C. Müller \& K. Strøm (Eds.), Coalition Governments in Western Europe. Oxford: Oxford University Press. 
McDonnell, D. \& Valbruzzi, M. (2014). Defining and Classifying Technocrat-Led and Technocratic Governments. European Journal of Political Research 53(4): 654-671.

Pastorella, G. (2016). Technocratic Governments: Power, Expertise and Crisis Politics in European Democracies. London: London School of Economics.

Pilet J. B. (2012). Executive-Legislative Relations without a Government. European Political Science 11(1): 96-101.

Rigaux, L. (2020). Les pouvoirs du gouvernement en affaires courantes et ses rapports avec le parlement. Revue belge de droit constitutionnel 2(online).

Schleiter, P. \& Belu,V. (2015). The Challenge of Periods of Caretaker Government in the UK. Parliamentary Affairs 68: 229-247.

Tiernan, A. \& Menzies, J. (2007). Caretaker Conventions in Australasia: Minding the Shop for Government. Canberra:ANU Press.

Van Aelst, P. \& Louwerse,T. (2014). Parliament without Government:The Belgian Parliament and the Government Formation Processes of 2007-2011. West European Politics 37(3): 475-496.

Zafarullah, H. \& Yeahia Akhter, M. (2000). Non-Political Caretaker Administrations and Democratic Elections in Bangladesh: An Assessment. Government and Opposition 35(3): 345-369. 